\title{
Species of Fusarium Isolated from River and Sea Water of Southeastern Spain and Pathogenicity on Four Plant Species
}

\author{
D. Palmero and C. Iglesias, Universidad Politécnica de Madrid, EUIT Agrícola, Ciudad Universitaria s/n, 28040- \\ Madrid, Spain; and M. de Cara, T. Lomas, M. Santos, and J. C. Tello, Universidad de Almería, Dpto. Producción \\ Vegetal, Cañada de San Urbano s/n, 04120-Almería, Spain
}

\begin{abstract}
Palmero, D., Iglesias, C., de Cara, M., Lomas, T., Santos, M., and Tello, J. C. 2009. Species of Fusarium isolated from river and sea water of southeastern Spain and pathogenicity on four plant species. Plant Dis. 93:377-385.

Species of Fusarium were isolated from water samples collected from the Andarax River and coastal sea water of the Mediterranean in Granada and Almería provinces of southeastern Spain. In total, 18 water samples were analyzed from the Andarax River, and 10 species of Fusarium were isolated: Fusarium anthophilum, F. acuminatum, F. chlamydosporum, F. culmorum, F. equiseti, F. verticillioides, F. oxysporum, F. proliferatum, F. solani, and F. sambucinum. In addition, five species were isolated from 33 sea water samples from the Mediterranean Sea: F. equiseti, $F$. verticillioides, $F$. oxysporum, $F$. proliferatum, and $F$. solani. When considering the samples by their origins, $77.8 \%$ of the river water samples yielded at least one species of Fusarium, with $F$. oxysporum comprising $72.2 \%$ of the total isolates. In the case of marine water, $45.5 \%$ of the samples yielded at least one species of Fusarium, with F. solani comprising $36.3 \%$ of the total isolates. The pathogenicity of 41 isolates representing nine of the species collected from river and sea water during the study was evaluated on barley, kohlrabi, melon, and tomato. Inoculation with $F$. acuminatum, $F$. chlamydosporum, F. culmorum, $F$. equiseti, $F$. verticillioides, $F$. oxysporum, $F$. proliferatum $F$. solani, and $F$. sambucinum resulted in pre- and post-emergence damping off. Pathogenicity of Fusarium isolates did not seem to be related to the origin of the isolates (sea water or fresh water). However, the presence of pathogenic species of Fusarium in river water flowing to the sea could indicate long-distance dispersal in natural water environments.
\end{abstract}

Almeria and Granada provinces, in the southeast of the Iberian Peninsula, stretch along $330 \mathrm{~km}$ of coastline on the Mediterranean Sea (Fig. 1). Along the shore, intensive agriculture using plastic greenhouses for production of vegetable crops (tomato, watermelon, pepper, bean, eggplant, and squash.) occurs, and subtropical crops (avocado, cherimoya, and sugar cane) are grown in the field. The main water source in this area is the Andarax River. The river's water is used for irrigation and, as a result, the main part of its course is dry most of the year.

Diseases produced by species of Fusarium are common in these areas. They were in the past, and are still today, a problem for greenhouses crops in Almería.

The following species have been listed as pathogens on agricultural crops in this region: Fusarium oxysporum f. sp. lycopersici (race 0 and 1) (54), F. oxysporum f. sp. melonis (race 0, 1, 2, and 1-2) (50), F. oxysporum f. sp. niveum (49), $F$. ox-

Corresponding author: D. Palmero

E-mail: daniel.palmero@upm.es

Accepted for publication 16 December 2008.

doi:10.1094/PDIS-93-4-0377

(C) 2009 The American Phytopathological Society ysporum f. sp. melongenae $(49,60), F$. oxysporum f. sp. basilici (21), $F$. oxysporum f. sp. asparagi (11,51), F. oxysporum f. sp. dianthi (54), F. oxysporum f. sp. radicis-lycopersici (53), Fusarium oxysporum f. sp. radicis-cucumerinum (30), F. solani in broad bean (Vicia faba; 52), pea (Pisum sativum; 56) and French bean (Phaseolus vulgaris; 55), F. proliferatum (asparagus) (11,13), F. culmorum (asparagus and carnation) (11,51), and $F$. equiseti (broad bean; 52).

Research that has focused on the occurrence of the genus in aquatic habitats is not common, perhaps because Fusarium spp. Generally are considered to be soilborne fungi. Backhouse et al. (2) published an extensive study on the biogeography of Fusarium spp. in Australia, but the aquatic habitat was not covered. Fusarium spp. have been reported in marshy waters (19), and $F$. merismoides was found by Booth (4) in polluted water and mud. Articles on fungi in fluvial and lacustrine water mention the presence of Fusarium spp., but as a decomposer of leaves and branches from fallen trees in river channels $(8,9,40,62)$. The spread of Fusarium spp. via irrigation water has also been described for some species causing plant diseases in greenhouses (14).

The presence of Fusarium spp. is not mentioned in marine aquatic research lit- erature concerning the study of the Fungi Imperfecti $(1,17,38) . \quad F$. oxysporum, $F$. solani, and $F$. semitectum have been isolated from the rhizosphere soil of mangrove $(47,48)$. Rebell (39) reported a high recovery of $F$. solani from calcareous beach sands in Florida and the Caribbean islands. $F$. solani commonly occurs in lesions sustained by loggerhead sea turtles (Caretta caretta; 7). More recently, several species of Fusarium have been described as causing diseases in marine animals $(10,15,22,26,41)$.

Tello and Lacasa (57) studied the presence of species of Fusarium in uncultivated land, finding a high proportion of $F$. solani and $F$. oxysporum. These authors questioned the relationship between the isolated species (especially $F$. oxysporum) and those that produced diseases in crops surrounding the sampled uncultivated ground. Tello et al. $(57,58)$ also studied species of Fusarium isolated from beach sands in Spain. They reported $F$. oxysporum, $F$. solani, $F$. equiseti, $F$. acuminatum, $F$. chlamydosporum var. fuscum, $F$. reticulatum var. majus, $F$. moniliforme (sensu lato), and F. merismoides. Recently, Nuñez et al. (34) recovered $F$. oxysporum and $F$. equiseti at $7.2,9.0$, and $27.0 \mathrm{~m}$ in depth and $F$. acuminatum at $27.0 \mathrm{~m}$ in depth in the bay of Almeria, supporting the findings of Tello et al. (58) on the occurrence of Fusarium spp. in beach sand on the Mediterranean shore. This study, like others, did not address whether or not the Fusarium spp. isolated from this habitat were pathogenic to crops in the sampled areas.

The purpose of this study was to collect and identify the species of Fusarium present in the Andarax River and Andarax dry riverbeds of southeastern Spain. In addition, the distribution of Fusarium spp. at different depths in marine water along the Mediterranean shore of the southeastern Iberian Peninsula was ascertained.

\section{MATERIALS AND METHODS}

Andarax River and riverbed sampling. The Andarax River and one of its tributaries, the Isfalada River, which partially run across the mountainous areas of Granada, is the only water source in Almeria province (Fig. 1), an arid region characterized by intensive agriculture in plastic greenhouses. Sampling was designed to discover whether the Andarax 
River contained Fusarium spp. at its source. In all, 2 samples (Riv1 and Riv2) were collected at the headwaters of the river basin (Fig. 2) and 13 samples (Riv3 to Riv16) from four different locations along $67 \mathrm{~km}$ of the river channel (Tabernas, Gador, Pechina, and N340) were obtained after significant rainfall events when the river flowed all the way to the sea. Riv17 and Riv18 samples (Fig. 2) were collected from stagnant water at the mouth of the river that could have originated from rain-induced overflow (hereafter referred to as freshet). However, the water also could have been sea water from the surf. All water samples were manually collected in 200-ml sterile plastic jars (Eurotubo Deltalab, Barcelona, Spain) that were not opened until placement in the water. Sampling times were December 2003 and March, June, and October 2004. After collecting, samples were taken to the laboratory for analysis within 24 to $48 \mathrm{~h}$. Dates and locations of the samples are summarized in Table 1 and Figure 2.

Analysis of the water samples involved gently shaking each jar, transferring $1 \mathrm{ml}$ of the water sample to a $9-\mathrm{cm}$ petri dish containing $10 \mathrm{ml}$ of selective medium cooled to $35^{\circ} \mathrm{C}$, and gently agitating the mixture to assure fusion of the sample water and agar. Thirty-two dishes per sample were set up in this way and randomly divided into four blocks of eight dishes. Plates were incubated for 10 days at laboratory temperature $\left(25^{\circ} \mathrm{C}\right)$ under continuous fluorescent light.

In order to determine whether Fusarium spp. were present in the sandy riverbed mouth, dry soil samples (Dry1, Dry2, Dry3, Dry4, and Dry5) were collected here in September 2004, 75 days after the last day in which the channel had carried water to the sea. Analysis of soil samples from the Andarax riverbed consisted of drying the soil under aseptic conditions at room temperature $\left(20\right.$ to $\left.25^{\circ} \mathrm{C}\right)$, crushing, then sifting the sample through a $200-\mu \mathrm{m}$ sieve and adding $0.02 \mathrm{~g}$ of the sifted soil to a Fusarium-selective medium as described by Komada (27) and modified by Tello et al. (59).

In total, 18 water samples from the river and five soil samples from the dry riverbed were analyzed. Sixteen petri dishes per sample were used and divided into four blocks of four dishes. Plates were incubated for 10 days at laboratory temperature under continuous fluorescent light. The mean number of CFU per petri dish and the standard deviation of the mean was calculated for all Fusarium colonies and used as the basis for comparisons.
Coastal sea water sampling in the provinces of Almeria and Granada. In Almeria, 20 seawater samples were collected from the Andarax River delta (Table 1; Fig. 2), distributed along the intertidal zone on the beach to about $100 \mathrm{~m}$ away from the mean high tide line (mhtl) at depths of $0 \mathrm{~m}$ (Sea4 to Sea8), $2 \mathrm{~m}$ (Sea9 to Sea13), $4 \mathrm{~m}$ (Sea14 to Sea18), and $6 \mathrm{~m}$ (Sea13 to Sea23) (Fig. 2). Other samples (Sea1, Sea2, and Sea3) already had been collected 1 month earlier at different depths (Table 1) in the same location. Along the coast of Granada, three seawater samples (Sea24 to Sea26) were collected at different depths at the mouth of the Albuñol River. In this area, there is intense agricultural activity in greenhouses located adjacent to the beach. Soil samples were collected at distances of 50,150, and $300 \mathrm{~m}$ from the mhtl (Table 1; Fig. 3). In the Cabo de Gata-Nijar Natural Parck where there is no fluvial channel mouth or agricultural activity, seven sea bed samples (Sea27 to Sea33) were collected at depths of approximately $4.5 \mathrm{~m}$ (Table 1; Fig. 2). Three of the samples (Sea27 to Sea29) were separated from one another by 150 $\mathrm{m}$ and also separated from the other four samples (Sea30 to Sea33) by about 1,500 m (Table 1; Fig. 2).

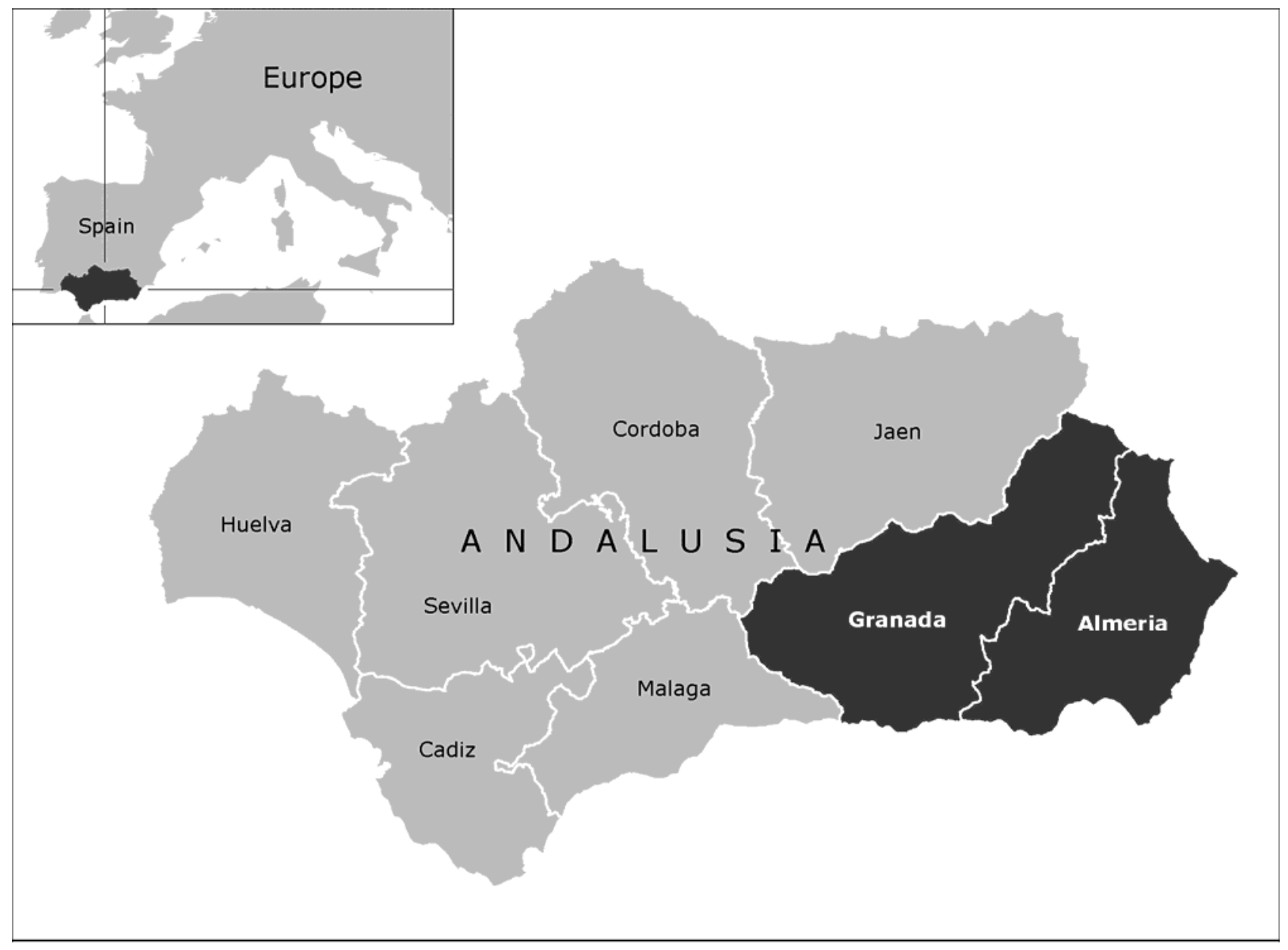

Fig. 1. Geographical location of Almeria and Granada provinces (southeastern Spain). 
Sea water samples were analyzed following the same methodology as indicated for river water samples.

Maintenance and identification of Fusarium spp. The whole collection was maintained on potato dextrose agar (PDA) and Komada's media and stored at $4^{\circ} \mathrm{C}$ in the fungus collection of the Plant Production Department of the University of Almeria and in the Polytechnic University of Madrid. The identification procedures and taxonomic criteria of Nelson et al. (32) and Leslie and Summerell (28) were followed to assign isolates to the Fusarium spp. level.

Pathogenicity tests. In total, 41 isolates of Fusarium (Table 2) obtained during both river and marine water sampling were inoculated onto barley (Hordeum vulgare L.) cv. CCE6, melon (Cucumis melo L.) cv. Canary yellow, kohlrabi (Brassica oleracea L. var. gongylodes) cv. Nabicol, and tomato (Lycopersicon esculentum Mill.) cv. Marmande. These species were chosen because they are the main herbaceous crops in Almeria and Granada provinces. Seed were first disinfected with sodium hypochlorite (active $\mathrm{Cl}_{2}$ at 40 to 50 $\mathrm{mg} / \mathrm{liter}$ ) for $15 \mathrm{~min}$, washed with sterilized water, then germinated in paper toweling over 3 to 7 days at room temperature (20 to $25^{\circ} \mathrm{C}$ ).
Inoculation tests followed a modification of the technique proposed by Messiaen et al. (29). Inoculum for each isolate was prepared by growing the culture for 2 weeks in complete darkness on PDA plates kept at $25^{\circ} \mathrm{C}$ until the colony reached the edge of the dish. Plastic 350-ml greenhouse pots were filled to two-thirds capacity with disinfected $\left(30 \mathrm{~min}\right.$ at $\left.120^{\circ} \mathrm{C}\right)$ vermiculite substrate (Agroalse S.L. Poligono Virgen de los Dolores, 220, no. 15; Valencia, Spain). A fungal colony was then scraped off a PDA plate and added to the surface of a pot; three pots were used per Fusarium isolate. Then, 10 pregerminated seeds (with a root length of 1 to $2 \mathrm{~cm}$ at the time of sowing) were placed into each pot and covered with a surface layer of 1 $\mathrm{cm}$ of disinfected vermiculite. Once the pot was full, it was watered until saturation, and then with $250 \mathrm{ml}$ of water every 2 days. Care was taken to keep pot leachates from contaminating other pots by keeping inoculated pots with different isolates in different trays and removing excess water from the trays daily. A sterile agar control was included in the inoculation test for each species of Fusarium tested. Inoculated and control plants were kept in a growth chamber set at 25 to $28^{\circ} \mathrm{C}$ under a photoperiod of $16 \mathrm{~h}$ at 12,000 lux
Plants in plots were rated every 5 days for percent emergence. After 20 days, plants were evaluated for the percent damping off (44) and pregerminated seed that did not emerge were uncovered and symptoms evaluated for root rot and seed rot (hereafter referred to as preemergence damping off). Reisolation and identification of Fusarium spp. were done on PDA medium for all plants and isolates. The experiment was repeated.

Statistical analysis of data. Analysis of variance on the isolates of Fusarium used for the inoculation test were carried out using STATGRAPHICS Plus 5.1 statistical package software (StatPoint, Inc., Herndon, VA). Data on percent damping off in test 1 and test 2 were not significantly different $(P=0.05)$, and were combined for analysis.

\section{RESULTS}

Analysis of water samples from the Andarax River. No species of Fusarium were recovered from the headwaters of the Andarax River. However, 18 water samples from the Andarax River yielded a total of 1,059 isolates of Fusarium (Fig. 2; Table $3)$. Of these, 351 isolates $(33.1 \%)$ were identified as $F$. oxysporum, $292(27.6 \%)$ as F. solani, $229(21.6 \%)$ as $F$. equiseti, 78 $(7.4 \%)$ as $F$. culmorum, $52(4.9 \%)$ as $F$.

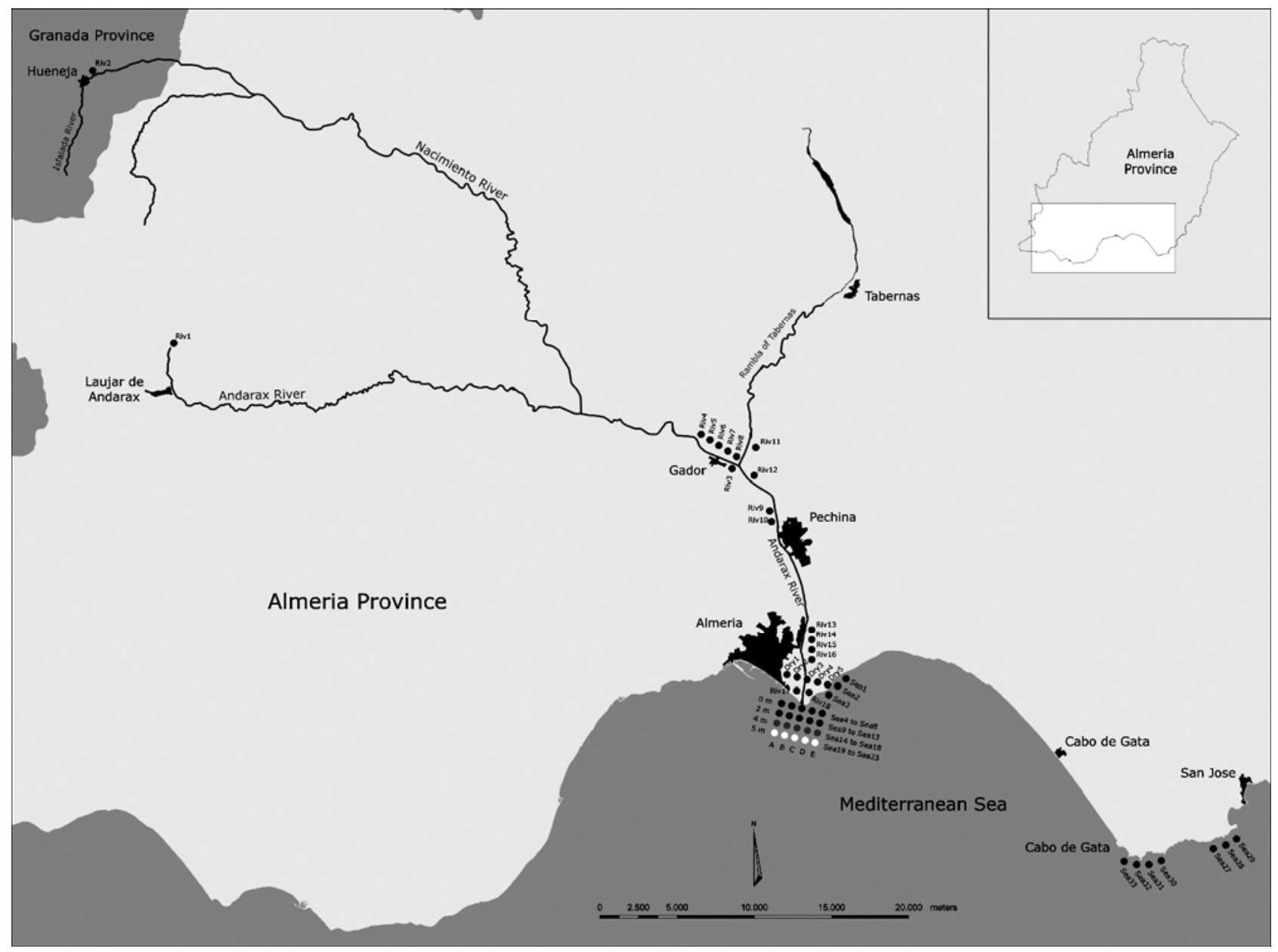

Fig. 2. Location of water samples collected from the Andarax and Isfalada Rivers and marine waters from the coast of Almería in southeastern Spain. 
chlamydosporum, $19(1.8 \%)$ as $F$. verticillioides, $16(1.5 \%)$ as $F$. acuminatum, 14 $(1.4 \%)$ as $F$. sambucinum, $6(0.6 \%)$ as $F$. proliferatum, and $2(0.2 \%)$ as $F$. anthophilum (sensu Nelson et al. [32] and Gerlach and Nirenberg [18]). No Fusarium spp. were isolated at the headwaters of the river basin (Riv1 and Riv2).

Samples Riv17 and Riv18 were collected after 75 days of drought, during which time the channel remained dry (Ta- ble 3). From these samples, four isolates were assigned to $F$. equiseti, two isolates to $F$. oxysporum, and one to $F$. verticillioides. No Fusarium spp. were isolated from the dry riverbed samples (Dry1 to Dry5).

Coastal water sampling. Analysis of water samples from Mediterranean coastal areas along the mouth of the Andarax River (Fig. 2) (Sea1 to Sea3) showed the presence of $F$. solani. When samples were collected at depths greater than $1.5 \mathrm{~m}, F$. oxysporum, $F$. equiseti, and $F$. verticillioides were also recovered (Table 3 ). In a larger sampling made 78 days after the last freshet from the river to the sea (Sea4 to Sea23), 15 isolates in total were identified as $F$. equiseti. Results showed the absence of $F$. oxysporum and presence of $F$. solani and $F$. equiseti in 6 and 9 samples, respectively, out of a total of 20 analyzed samples.

In the analysis of water samples from the Mediterranean Sea taken at the mouth

Table 1. Date, code, location, and coordinates (European Datum 1950 UTM zone $30^{\circ} \mathrm{N}$ ) of water and dry riverbed samples from the Andarax River and marine water samples from the coast of Almeria and Granada

\begin{tabular}{|c|c|c|c|c|c|}
\hline \multirow[b]{2}{*}{ Origin, date } & \multirow[b]{2}{*}{ Analysis code } & \multirow[b]{2}{*}{ Geographic location } & \multirow[b]{2}{*}{ Depth $(\mathbf{m})^{\mathbf{a}}$} & \multicolumn{2}{|c|}{ Coordinates } \\
\hline & & & & $\mathbf{X}$ & $\mathbf{Y}$ \\
\hline \multicolumn{6}{|l|}{ River samples } \\
\hline 07/03/2004 & Riv1 & Source of Andarax River (Laujar) & NA & 510115 & 4097286 \\
\hline 07/03/2004 & Riv2 & Isfalada River, tributary of Andarax & NA & 504864 & 4114756 \\
\hline \multirow[t]{2}{*}{$12 / 22 / 2003$} & Riv3 & Gador & NA & 545687 & 4090006 \\
\hline & Riv4 & Gador & NA & 545098 & 4090435 \\
\hline \multirow[t]{2}{*}{$3 / 25 / 2004$} & Riv5 & Gador & NA & 545284 & 4090359 \\
\hline & Riv6 & Gador & NA & 545472 & 4090282 \\
\hline \multirow[t]{6}{*}{$6 / 22 / 2004$} & Riv7 & Gador & NA & 545661 & 4090201 \\
\hline & Riv8 & Gador & NA & 545849 & 4090122 \\
\hline & Riv9 & Pechina & NA & 549372 & 4086274 \\
\hline & Riv10 & Pechina & NA & 549437 & 4085880 \\
\hline & Riv11 & Rambla of Tabernas & NA & 574058 & 4090020 \\
\hline & Riv12 & Rambla of Tabernas & NA & 546940 & 4089634 \\
\hline \multirow{4}{*}{$10 / 09 / 2004$} & Riv13 & Highway N340 & NA & 551059 & 4074998 \\
\hline & Riv14 & Highway N340 & NA & 551047 & 4074797 \\
\hline & Riv15 & Highway N340 & NA & 551041 & 4074596 \\
\hline & Riv16 & Highway N340 & NA & 551024 & 4074396 \\
\hline \multirow[t]{2}{*}{$12 / 22 / 2003$} & Riv17 & Stagnant water at the mouth of the Andarax river & 0.10 & 550876 & 4074383 \\
\hline & Riv18 & & 0.10 & 550927 & 4074371 \\
\hline \multirow[t]{5}{*}{$09 / 05 / 2004$} & Dry1 & Dry riverbed at the mouth of the Andarax river & NA & 550876 & 4077383 \\
\hline & Dry2 & Dry riverbed at the mouth of the Andarax river & NA & 550927 & 4074371 \\
\hline & Dry3 & Dry riverbed at the mouth of the Andarax river & NA & 550981 & 4074359 \\
\hline & Dry4 & Dry riverbed at the mouth of the Andarax river & NA & 551039 & 4074345 \\
\hline & Dry5 & Dry riverbed at the mouth of the Andarax river & NA & 551092 & 4074334 \\
\hline \multicolumn{6}{|l|}{ Sea samples } \\
\hline \multirow[t]{3}{*}{ 07/11/2004 } & Sea1 & Mouth of Andarax Riverbed & 0.10 & 551169 & 4074231 \\
\hline & Sea2 & Mouth of Andarax Riverbed & 1.50 & 551238 & 4074229 \\
\hline & Sea3 & Mouth of Andarax Riverbed & 4 & 551310 & 4074247 \\
\hline \multirow[t]{20}{*}{$08 / 09 / 2004$} & Sea4 & Border of the sea & 0.10 & 550856 & 4074317 \\
\hline & Sea5 & Border of the sea & 0.10 & 550908 & 4074291 \\
\hline & Sea6 & Border of the sea & 0.10 & 550961 & 4074271 \\
\hline & Sea7 & Border of the sea & 0.10 & 551025 & 4074264 \\
\hline & Sea8 & Border of the sea & 0.10 & 551079 & 4074239 \\
\hline & Sea9 & Sea bed & 2 & 550815 & 4074176 \\
\hline & Sea10 & Sea bed & 2 & 550868 & 4074145 \\
\hline & Sea11 & Sea bed & 2 & 550925 & 4074126 \\
\hline & Sea12 & Sea bed & 2 & 550987 & 4074116 \\
\hline & Sea13 & Sea bed & 2 & 551047 & 4074088 \\
\hline & Sea14 & Sea bed & 4 & 550771 & 4074032 \\
\hline & Sea15 & Sea bed & 4 & 550826 & 4074000 \\
\hline & Sea16 & Sea bed & 4 & 550886 & 4073982 \\
\hline & Sea17 & Sea bed & 4 & 550951 & 4073965 \\
\hline & Sea18 & Sea bed & 4 & 551012 & 4073937 \\
\hline & Sea19 & Sea bed & 6 & 550729 & 4073888 \\
\hline & Sea20 & Sea bed & 6 & 550786 & 4073856 \\
\hline & Sea21 & Sea bed & 6 & 550844 & 4073833 \\
\hline & Sea22 & Sea bed & 6 & 550913 & 4073823 \\
\hline & Sea23 & Sea bed & 6 & 550976 & 4073798 \\
\hline \multirow[t]{3}{*}{$07 / 11 / 2004$} & Sea24 & Mouth of Albuñol Riverbed & 4.50 & 485881 & 4066493 \\
\hline & Sea25 & Mouth of Albuñol Riverbed & 1.50 & 485772 & 4066598 \\
\hline & Sea26 & Mouth of Albuñol Riverbed & 0.50 & 485663 & 4066703 \\
\hline $11 / 17 / 2004$ & Sea27 & Under the "Cabo de Gata" lighthouse & 4.50 & 577695 & 4065379 \\
\hline & Sea 28 & Under the "Cabo de Gata" lighthouse & 4.50 & 578141 & 4065526 \\
\hline & Sea29 & Under the "Cabo de Gata" lighthouse & 4.50 & 578619 & 4065573 \\
\hline & Sea30 & "Cabo de gata" & 4.50 & 572024 & 4064268 \\
\hline & Sea31 & "Cabo de gata" & 4.50 & 572322 & 4064225 \\
\hline & Sea32 & "Cabo de gata" & 4.50 & 572643 & 4064257 \\
\hline & Sea33 & "Cabo de gata" & 4.50 & 573207 & 4064287 \\
\hline
\end{tabular}

\footnotetext{
${ }^{\text {a }} \mathrm{NA}=$ not applicable.
} 
of the Albuñol River (Sea24 to Sea26), five isolates were identified as $F$. solani, four isolates as $F$. oxysporum, and two isolates as $F$. equiseti. When samples were collected at depths greater than $1.5 \mathrm{~m}$, five isolates were identified as $F$. verticillioides and two as $F$. proliferatum. $F$. oxysporum and $F$. solani were also isolated from a depth of $4.5 \mathrm{~m}$ (Fig. 2).

Pathogenicity test. Barley was the most susceptible host; $61.0 \%$ of the isolates caused preemergence damping off on the seedlings. Melon followed in susceptibility, with $40.8 \%$ of the isolates caused preemergence damping off on the seedlings. On kohlrabi, $39.4 \%$ of the tested isolates were pathogenic. Tomato was least susceptible, with $36.6 \%$ of the tested isolates causing preemergence damping off. Post-emergence damping off was caused by $73.2 \%$ of the isolates inoculated on melon, $41.5 \%$ on barley, and 14.6 and $19.5 \%$ on kohlrabi and tomato, respectively.

F. acuminatum caused seed coat decay and root rot on barley and kohlrabi seedlings but did not cause symptoms on seedlings once they emerged (Table 4). In the case of melon and tomato, only one isolate of $F$. acuminatum produced a reaction on the emergence of pregerminated seed but both isolates caused significant death of seedlings once they emerged.

None of the three isolates of F. chlamydosporum were pathogenic on barley. On kohlrabi, only one isolate caused significant decrease in seedling emergence. On melon, one isolate of $F$. chlamydoporum caused severe post-emergence damping off.

Most of the isolates of $F$. culmorum (eight of nine) caused pronounced damping off on barley post emergence. Conversely, kohlrabi seedlings were affected by $F$. culmorum causing damping off prior to emergence. Four isolates of $F$. culmorum were pathogenic on melon. On tomato, only one isolate was pathogenic after emergence.

Barley and kohlrabi seedlings were affected by $F$. equiseti causing damping off during preemergence but it did not cause symptoms ones seedlings emerged. Only one isolate of $F$. equiseti caused preemergence damping off on melon but four isolates were pathogenic after emergence. On tomato, three isolates caused damping off in preemergence.

Only one $F$. verticillioides isolate produced significant decrease in seedling emergence on barley. No pathogenicity was detected on kohlrabi either pre- or post emergence. On melon, one isolate reduced emergence significantly and two of three isolates caused damping off after emergence. On tomato, one isolate of $F$. verticillioides significantly reduced emergence but all three isolates caused significant damping off post emergence.

None of the two isolates of $F$. oxysporum were pathogenic on barley and kohlrabi. On melon, F. oxysporum isolates were pathogenic after emergence. On tomato, one of the isolates reduced emergence significantly. Seed and root rot were observed in not-emerged seedlings.

Four isolates of $F$. proliferatum produced an extensive preemergence damping off on barley but none of the isolates produced symptoms after emergence. Three isolates produced a significant decline in emergence on kohlrabi but did not cause symptoms once seedlings emerged. On melon, two isolates of $F$. proliferatum reduced emergence but they were slightly pathogenic after emergence. Those isolates that drastically reduced emergence in barley also did so on tomato, and two more strains of $F$. proliferatum slightly reduced emergence on tomato seedlings. Results showed no pathogenicity on tomato post emergence.

No isolates of $F$. solani were pathogenic on barley. Only one F. solani isolate produced significant decrease in seedling emergence on kohlrabi. All the isolates of $F$. solani caused damping off on melon seedlings during preemergence but did not

Table 2. Origin of the isolates of species of Fusarium used in greenhouse seedling inoculation studies

\begin{tabular}{llll}
\hline Sample code & Code of isolate & \multicolumn{1}{c}{ Sample and origin of the isolate } & Species of Fusarium \\
\hline Riv5 & Fac1-Fac2 & Andarax River water & F. acuminatum \\
Riv5 & Fch11-Fch13 & Andarax River water & F. chlamydosporum \\
Riv5 & Fcu1-Fcu9 & Andarax River water & F. culmorum \\
Sea3 & Feq1-Feq2 & Sea water mouth of the Andarax River & F. equiseti \\
Riv15 & Feq3-Feq7 & Andarax River water & F. equiseti \\
Sea25 & Fox1-Fox2 & Sea water. Mouth of the Albuñol River & F. oxysporum \\
Sea24 & Fver1 & Sea water. Mouth of the Albuñol River & F. verticillioides \\
Sea3 & Fver2-Fver3 & Sea water. Mouth of the Andarax River & F. verticillioides \\
Sea24 & Fpro1-Fpro2 & Sea water. Mouth of the Albuñol River & F. proliferatum \\
Riv5 & Fpro3 & Andarax River water & F. proliferatum \\
Sea24 & Fpro4-Fpro5 & Sea water. Mouth of the Albuñol River & F. proliferatum \\
Riv13 & Fcu10-Fcu11 & Andarax River water & F. sambucinum \\
Sea3 & Fso1-Fso8 & Sea water. Mouth of the Andarax River & F. solani \\
\hline
\end{tabular}

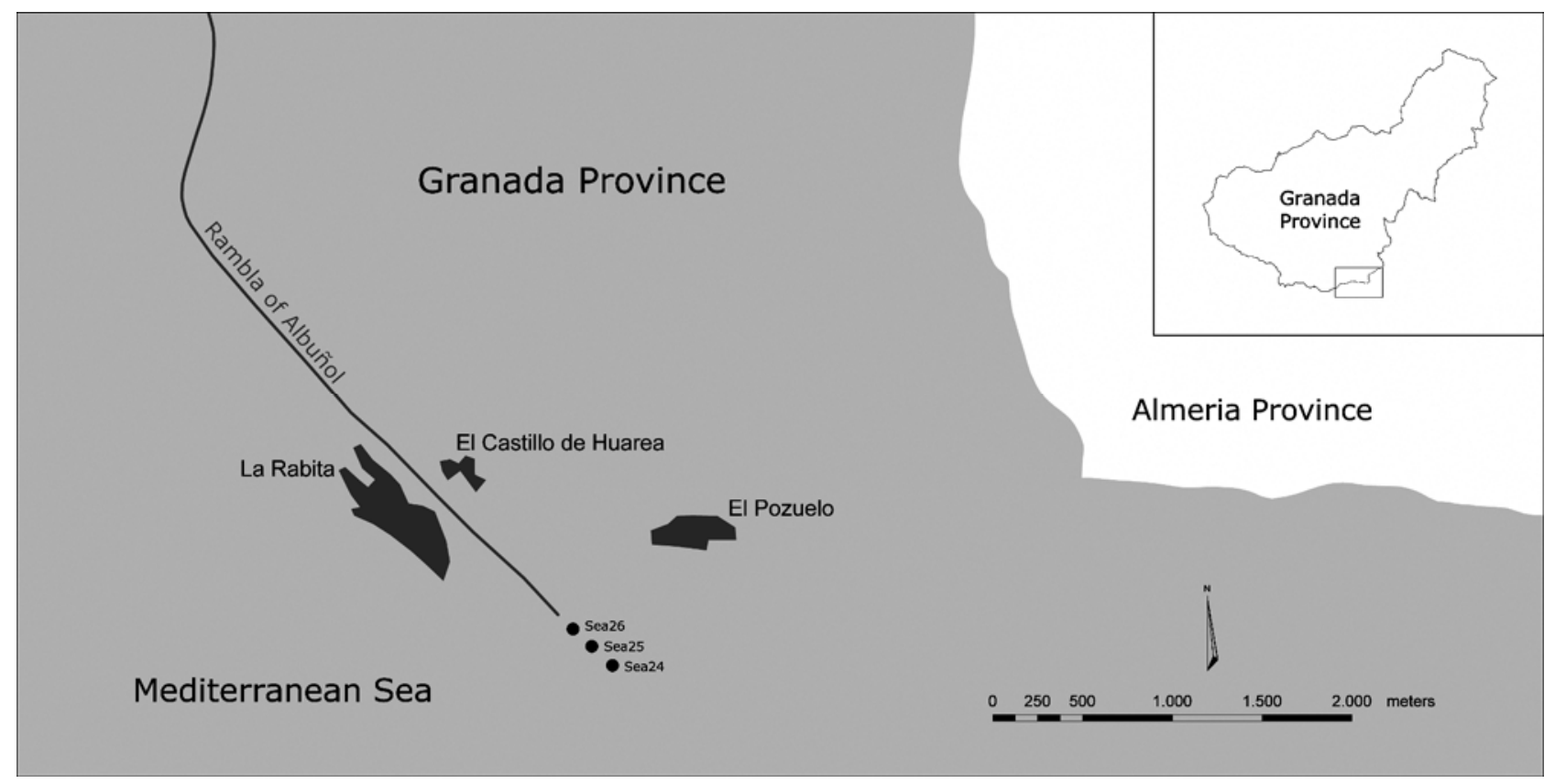

Fig. 3. Location of marine water samples collected from the coast of Granada in southeastern Spain. 
cause symptoms once seedlings emerged. On tomato, two isolates showed significant effects in emergence and four isolates caused significant damping off post emergence.

Two isolates of $F$. sambucinum caused pronounced damping off on barley post emergence. Neither of the two isolates of F. sambucinum were pathogenic on kohlrabi, tomato, and melon.

Sterile agar controls developed no symptoms on seedlings. The respective Fusarium isolates were recovered and identified from all infected, inoculated plants.

\section{DISCUSSION}

In total 1,114 isolates and 10 different species of Fusarium obtained from 51 samples of river and marine water collected in southeastern Spain were identi- fied. Of these, $95.06 \%$ originated from river water, and $77.8 \%$ of the river water samples yielded at least one species of Fusarium, with $F$. oxysporum comprising $72.2 \%$ of the total isolates. No isolates of Fusarium were obtained at the headwaters of the river basin. Most of the isolates were obtained from samples at Gador during two different freshets occurring in March and June 2004 comprising 12.7 and 0.3 $\mathrm{mm}$ of total precipitation, respectively, and also from the mouth of the river in October 2004 with $1.5 \mathrm{~mm}$ (precipitation data provided by meteorological station no. 84870 LEAN); however, no seasonal or geographic pattern of Fusarium distribution was discernable.

The presence of Fusarium spp. in samples collected from the river channel as well as from the mouth of the river likely resulted after rainfall events, when flowing water carried particles of soil and organic matter from the riverbanks where crops were being grown.

Samples Riv17 and Riv18 were collected in areas very close to the line separating the sea from the river channel. These samples possibly represented water carried by either the river or the sea. Most remarkable was the absence of any species of Fusarium in riverbed soil at the point where river water enters the sea. This finding supports the hypothesis that these species which are carried by river water do not originate from dry riverbeds but, rather, from the run-off of cultivated fields adjacent to the riverbanks.

During this study, $4.9 \%$ of isolates were collected from sea water. In the case of marine water, $45.5 \%$ of the samples yielded at least one species of Fusarium, with $F$. solani comprising $36.3 \%$ of the

Table 3. Presence of species of Fusarium in river water and dry riverbed samples obtained from the Andarax River and in marine water samples obtained at the mouth of the Andarax and Albuñol Rivers in southeastern Spain

\begin{tabular}{|c|c|c|c|c|c|c|c|c|c|c|}
\hline \multirow[b]{2}{*}{ Origin $^{b}$} & \multicolumn{10}{|c|}{ Fusarium spp. recovered ${ }^{a}$} \\
\hline & F. oxy & F. sol & F. vert & F. pro & F. anth & F. cul & F. samb & F. chlmy & F. acum & F.eq \\
\hline \multicolumn{11}{|l|}{ River } \\
\hline Riv1 & $0 \pm 0$ & $0 \pm 0$ & $0 \pm 0$ & $0 \pm 0$ & $0 \pm 0$ & $0 \pm 0$ & $0 \pm 0$ & $0 \pm 0$ & $0 \pm 0$ & $0 \pm 0$ \\
\hline Riv2 & $0 \pm 0$ & $0 \pm 0$ & $0 \pm 0$ & $0 \pm 0$ & $0 \pm 0$ & $0 \pm 0$ & $0 \pm 0$ & $0 \pm 0$ & $0 \pm 0$ & $0 \pm 0$ \\
\hline Riv3 & $0 \pm 0$ & $0 \pm 0$ & $0 \pm 0$ & $1 \pm 1$ & $0 \pm 0$ & $0 \pm 0$ & $0 \pm 0$ & $0 \pm 0$ & $0 \pm 0$ & $0 \pm 0$ \\
\hline Riv4 & $14 \pm 8$ & $2 \pm 1$ & $1 \pm 1$ & $1 \pm 1$ & $0 \pm 0$ & $6 \pm 2$ & $0 \pm 0$ & $0 \pm 0$ & $2 \pm 1$ & $8 \pm 3$ \\
\hline Riv5 & $64 \pm 8$ & $3 \pm 1$ & $5 \pm 4$ & $2 \pm 2$ & $1 \pm 1$ & $11 \pm 3$ & $2 \pm 1$ & $6 \pm 3$ & $3 \pm 2$ & $44 \pm 7$ \\
\hline Riv6 & $66 \pm 23$ & $6 \pm 6$ & $5 \pm 2$ & $0 \pm 0$ & $0 \pm 0$ & $9 \pm 3$ & $1 \pm 1$ & $2 \pm 1$ & $0 \pm 0$ & $5 \pm 2$ \\
\hline Riv7 & $42 \pm 18$ & $1 \pm 2$ & $1 \pm 1$ & $0 \pm 0$ & $0 \pm 0$ & $9 \pm 4$ & $0 \pm 0$ & $1 \pm 1$ & $0 \pm 0$ & $3 \pm 1$ \\
\hline Riv8 & $37 \pm 8$ & $2 \pm 2$ & $1 \pm 1$ & $1 \pm 1$ & $0 \pm 0$ & $6 \pm 2$ & $0 \pm 0$ & $2 \pm 1$ & $2 \pm 1$ & $3 \pm 2$ \\
\hline Riv9 & $2 \pm 2$ & $0 \pm 0$ & $0 \pm 0$ & $0 \pm 0$ & $0 \pm 0$ & $0 \pm 0$ & $0 \pm 0$ & $0 \pm 0$ & $1 \pm 1$ & $1 \pm 1$ \\
\hline Riv10 & $0 \pm 1$ & $0 \pm 0$ & $0 \pm 0$ & $0 \pm 0$ & $0 \pm 0$ & $0 \pm 0$ & $0 \pm 0$ & $0 \pm 0$ & $0 \pm 0$ & $1 \pm 1$ \\
\hline Riv11 & $1 \pm 1$ & $0 \pm 0$ & $0 \pm 0$ & $0 \pm 0$ & $0 \pm 0$ & $0 \pm 0$ & $0 \pm 0$ & $0 \pm 0$ & $0 \pm 0$ & $0 \pm 1$ \\
\hline Riv12 & $1 \pm 1$ & $0 \pm 0$ & $0 \pm 0$ & $0 \pm 0$ & $0 \pm 0$ & $0 \pm 0$ & $0 \pm 0$ & $0 \pm 0$ & $0 \pm 0$ & $0 \pm 1$ \\
\hline Riv13 & $8 \pm 4$ & $2 \pm 1$ & $1 \pm 1$ & $1 \pm 1$ & $0 \pm 0$ & $21 \pm 5$ & $2 \pm 2$ & $12 \pm 3$ & $3 \pm 2$ & $30 \pm 6$ \\
\hline Riv14 & $48 \pm 12$ & $81 \pm 16$ & $0 \pm 0$ & $0 \pm 0$ & $0 \pm 0$ & $12 \pm 4$ & $3 \pm 2$ & $9 \pm 3$ & $5 \pm 3$ & $36 \pm 7$ \\
\hline Riv15 & $37 \pm 16$ & $105 \pm 22$ & $0 \pm 0$ & $1 \pm 2$ & $0 \pm 0$ & $0 \pm 0$ & $0 \pm 0$ & $13 \pm 3$ & $0 \pm 0$ & $53 \pm 11$ \\
\hline Riv16 & $35 \pm 15$ & $91 \pm 26$ & $1 \pm 1$ & $0 \pm 0$ & $0 \pm 0$ & $0 \pm 0$ & $0 \pm 0$ & $7 \pm 2$ & $0 \pm 0$ & $47 \pm 8$ \\
\hline Riv17 & $1 \pm 1$ & $0 \pm 0$ & $1 \pm 1$ & $0 \pm 0$ & $0 \pm 0$ & $0 \pm 0$ & $0 \pm 0$ & $0 \pm 0$ & $0 \pm 0$ & $2 \pm 1$ \\
\hline Riv18 & $1 \pm 1$ & $0 \pm 0$ & $1 \pm 1$ & $0 \pm 0$ & $0 \pm 0$ & $0 \pm 0$ & $0 \pm 0$ & $0 \pm 0$ & $0 \pm 0$ & $2 \pm 1$ \\
\hline Dry1 & $0 \pm 0$ & $0 \pm 0$ & $0 \pm 0$ & $0 \pm 0$ & $0 \pm 0$ & $0 \pm 0$ & $0 \pm 0$ & $0 \pm 0$ & $0 \pm 0$ & $0 \pm 0$ \\
\hline Dry2 & $0 \pm 0$ & $0 \pm 0$ & $0 \pm 0$ & $0 \pm 0$ & $0 \pm 0$ & $0 \pm 0$ & $0 \pm 0$ & $0 \pm 0$ & $0 \pm 0$ & $0 \pm 0$ \\
\hline Dry3 & $0 \pm 0$ & $0 \pm 0$ & $0 \pm 0$ & $0 \pm 0$ & $0 \pm 0$ & $0 \pm 0$ & $0 \pm 0$ & $0 \pm 0$ & $0 \pm 0$ & $0 \pm 0$ \\
\hline Dry4 & $0 \pm 0$ & $0 \pm 0$ & $0 \pm 0$ & $0 \pm 0$ & $0 \pm 0$ & $0 \pm 0$ & $0 \pm 0$ & $0 \pm 0$ & $0 \pm 0$ & $0 \pm 0$ \\
\hline Dry5 & $0 \pm 0$ & $0 \pm 0$ & $0 \pm 0$ & $0 \pm 0$ & $0 \pm 0$ & $0 \pm 0$ & $0 \pm 0$ & $0 \pm 0$ & $0 \pm 0$ & $0 \pm 0$ \\
\hline \multicolumn{11}{|l|}{ Sea } \\
\hline Sea1 & $0 \pm 0$ & $0 \pm 0$ & $0 \pm 0$ & $0 \pm 0$ & $0 \pm 0$ & $0 \pm 0$ & $0 \pm 0$ & $0 \pm 0$ & $0 \pm 0$ & $0 \pm 0$ \\
\hline Sea2 & $0 \pm 0$ & $1 \pm 2$ & $0 \pm 0$ & $0 \pm 0$ & $0 \pm 0$ & $0 \pm 0$ & $0 \pm 0$ & $0 \pm 0$ & $0 \pm 0$ & $0 \pm 0$ \\
\hline Sea3 & $2 \pm 3$ & $15 \pm 4$ & $1 \pm 2$ & $0 \pm 0$ & $0 \pm 0$ & $0 \pm 0$ & $0 \pm 0$ & $0 \pm 0$ & $0 \pm 0$ & $1 \pm 2$ \\
\hline Sea4 & $0 \pm 0$ & $1 \pm 1$ & $0 \pm 0$ & $0 \pm 0$ & $0 \pm 0$ & $0 \pm 0$ & $0 \pm 0$ & $0 \pm 0$ & $0 \pm 0$ & $1 \pm 1$ \\
\hline Sea8 & $0 \pm 0$ & $1 \pm 1$ & $0 \pm 0$ & $0 \pm 0$ & $0 \pm 0$ & $0 \pm 0$ & $0 \pm 0$ & $0 \pm 0$ & $0 \pm 0$ & $0 \pm 0$ \\
\hline Sea9 & $0 \pm 0$ & $0 \pm 0$ & $0 \pm 0$ & $0 \pm 0$ & $0 \pm 0$ & $0 \pm 0$ & $0 \pm 0$ & $0 \pm 0$ & $0 \pm 0$ & $1 \pm 1$ \\
\hline Sea13 & $0 \pm 0$ & $0 \pm 0$ & $0 \pm 0$ & $0 \pm 0$ & $0 \pm 0$ & $0 \pm 0$ & $0 \pm 0$ & $0 \pm 0$ & $0 \pm 0$ & $1 \pm 1$ \\
\hline Sea14 & $0 \pm 0$ & $0 \pm 0$ & $0 \pm 0$ & $0 \pm 0$ & $0 \pm 0$ & $0 \pm 0$ & $0 \pm 0$ & $0 \pm 0$ & $0 \pm 0$ & $1 \pm 2$ \\
\hline Sea15 & $0 \pm 0$ & $0 \pm 0$ & $0 \pm 0$ & $0 \pm 0$ & $0 \pm 0$ & $0 \pm 0$ & $0 \pm 0$ & $0 \pm 0$ & $0 \pm 0$ & $1 \pm 1$ \\
\hline Sea18 & $0 \pm 0$ & $0 \pm 0$ & $0 \pm 0$ & $0 \pm 0$ & $0 \pm 0$ & $0 \pm 0$ & $0 \pm 0$ & $0 \pm 0$ & $0 \pm 0$ & $0 \pm 0$ \\
\hline Sea19 & $0 \pm 0$ & $1 \pm 2$ & $0 \pm 0$ & $0 \pm 0$ & $0 \pm 0$ & $0 \pm 0$ & $0 \pm 0$ & $0 \pm 0$ & $0 \pm 0$ & $0 \pm 0$ \\
\hline Sea20 & $0 \pm 0$ & $1 \pm 1$ & $0 \pm 0$ & $0 \pm 0$ & $0 \pm 0$ & $0 \pm 0$ & $0 \pm 0$ & $0 \pm 0$ & $0 \pm 0$ & $2 \pm 2$ \\
\hline Sea21 & $0 \pm 0$ & $1 \pm 1$ & $0 \pm 0$ & $0 \pm 0$ & $0 \pm 0$ & $0 \pm 0$ & $0 \pm 0$ & $0 \pm 0$ & $0 \pm 0$ & $2 \pm 1$ \\
\hline Sea22 & $0 \pm 0$ & $1 \pm 1$ & $0 \pm 0$ & $0 \pm 0$ & $0 \pm 0$ & $0 \pm 0$ & $0 \pm 0$ & $0 \pm 0$ & $0 \pm 0$ & $1 \pm 1$ \\
\hline Sea23 & $0 \pm 0$ & $0 \pm 0$ & $0 \pm 0$ & $0 \pm 0$ & $0 \pm 0$ & $0 \pm 0$ & $0 \pm 0$ & $0 \pm 0$ & $0 \pm 0$ & $1 \pm 2$ \\
\hline Sea24 & $1 \pm 3$ & $1 \pm 3$ & $5 \pm 4$ & $4 \pm 2$ & $0 \pm 0$ & $0 \pm 0$ & $0 \pm 0$ & $0 \pm 0$ & $0 \pm 0$ & $0 \pm 0$ \\
\hline Sea25 & $3 \pm 3$ & $3 \pm 6$ & $0 \pm 0$ & $0 \pm 0$ & $0 \pm 0$ & $0 \pm 0$ & $0 \pm 0$ & $0 \pm 0$ & $0 \pm 0$ & $1 \pm 3$ \\
\hline Sea26 & $0 \pm 0$ & $0 \pm 0$ & $0 \pm 0$ & $0 \pm 0$ & $0 \pm 0$ & $0 \pm 0$ & $0 \pm 0$ & $0 \pm 0$ & $0 \pm 0$ & $0 \pm 0$ \\
\hline
\end{tabular}

${ }^{a}$ F. oxy: Fusarium oxysporum; F. sol: F. solani; F. vert: F. verticillioides; F. pro: F. proliferatum; F. anth: F. anthopilum; Focal: F. culmorum; F. samb: F. sambucinum; F. chlmy: F. chlamydosporum; F. acum: F. acuminatum; and F. eq: F. equiseti.

${ }^{\mathrm{b}}$ Origin and sampling code for river and sea samples. Presence of species of Fusarium expressed in number of colonies per milliliter (UFC/ml of water) for Riv and Sea samples and number of colonies per gram (UFC/g of dry soil) for Dry samples, followed by the average standard deviation. 
total isolates. In sea water, $F$. oxysporum, $F$. solani, $F$. equiseti $F$. proliferatum, and $F$. verticillioides were recovered at a depth of $4 \mathrm{~m}$ near the Andarax River delta 15 days after the last freshet. If we assume that river water was the only influx of Fusarium spp., this indicates that these species came from the river and were able to survive in saline water during that period.

In a larger sampling made 78 days after the last freshet from the river to the sea, $F$. solani was found in the surface sample. $F$. equiseti was present at depths of 2 and $4 \mathrm{~m}$ and $F$. solani and $F$. equiseti were present at $6 \mathrm{~m}$. Of the species isolated from water gathered 15 days after the last freshet, $F$. solani and $F$. equiseti appeared again 78 days later. Such results suggest that these species might be able to remain alive in a saline aquatic medium for at least 2 months.

These results agree partly with those found by Tello et al. (58) regarding beach sands from the coast of Spain, with the difference that the former authors found $F$. merismoides and $F$. reticulatum var. majus in their samples, which were not identified in our study. The former study did not find F. culmorum, F. sambucinum, and F. proliferatum, which were obtained in our study. Our findings also agree with some of the species found by Núñez et al. (34) for coastal waters of the Mediterranean Sea at depths of 27.9 and $7.2 \mathrm{~m}: F$. $o x$ ysporum, $F$. equiseti, and $F$. acuminatum.

In the samples collected at the mouth of the Albuñol River, $F$. oxysporum and $F$ solani were isolated from depths of 1.5 and $4.5 \mathrm{~m}, F$. equiseti at $1.5 \mathrm{~m}$, and $F$. verticillioides and $F$. proliferatum at $4.5 \mathrm{~m}$. Both sampling areas are close to antropic areas with intense agricultural activity where marine winds are frequent and strong. These winds carry dust particles that can fall on the surface of the sea, which could also explain the presence of Fusarium spp. in the sea samples. Tello and Lacasa (54) showed that, on a $8.75-\mathrm{m}^{2}$ surface exposed to wind south of the Canary Islands, 12,598 UFC of $F$. solani and 8,712 UFC of $F$. verticillioides were recovered. In this sense, Burgess (5) wrote that, although the traditional ecological categories, soilborne and airborne, can be applied to the majority of Fusarium spp., evidence indicates that some populations can colonize substrates outside their accepted habitat. Based on our results, it is likely that the aquatic media under study do consistently harbor various Fusarium spp.

Certainly the populations we report are small compared with what is common in agricultural soils in the area ( $F$. oxysporum at 2,602 UFC/g, $F$. solani at $1,759 \mathrm{UFC} / \mathrm{g}$, and $F$ equiseti at $221 \mathrm{UFC} / \mathrm{g}$ on carnation crops; or F. oxysporum at $53 \mathrm{UFC} / \mathrm{g}$ of dry soil and $F$. equiseti at $131 \mathrm{UFC} / \mathrm{g}$ of dry soil on tomato crops) $(53,54)$, but they could be comparable with soils found in pine groves (54) and to beach sand $(34,58)$. Supposing that these species came only from the water flowing from the river to the sea, the first sampling was collected 19 days and the second 78 days, respectively, after the last freshet. The fact that the river might be the source of species of Fusarium in sea water can be supported by the absence of Fusarium spp. in seven sea water samples collected at Cabo de Gata, located in the Cabo de Gata-Nijar Natural Park, where there are no channel mouths or agricultural activities. In these samples, no species of Fusarium were isolated.

The study of the pathogenicity of 41 isolates from nine species of Fusarium showed that most of the isolates caused preemergence damping off on the seedlings.

The least pathogenic species of Fusarium were $F$. chlamydosporum and $F$. sambucinum, both prior to and after emergence. All the isolates within the two species used in the inoculation test were obtained from river water.

F. chlamydosporum could be considered a saprophyte, although Elmer (13) isolated it in association with asparagus root and crown disease and moderate pathogenicity has been reported in pea seedlings (18). F. sambucinum has been described as a cause of root rot and storage rot. It has also been reported attacking cereal seedlings (barley, maize, and oat), forest trees (3), potato (25), lupin, tomato, and strawberry (4).

The most pathogenic species on barley were $F$. culmorum and $F$. equiseti, both pre- and post emergence. All the F. culmorum isolates were obtained from river water whereas most of the inoculated isolates of F. equiseti (five of seven) were obtained from sea water. Booth (4) observed that $F$. culmorum can cause serious damage to cereals, including wheat, rye, barley, oat, and maize. F. culmorum has been associated with head blight of wheat and barley $(12,16,46)$ and it is considered to be the cause of Fusarium foot rot disease in cereals (6). Analytical results are consistent with these; isolates of $F$. culmorum from river water caused pronounced damping off on barley. In addition, F. culmorum has been mentioned as the source of diseases in other crops $(3,13,31)$.

$F$. equiseti can be found worldwide $(28,32)$. Messiaen and Casini (29) considered it to be typically soilborne. F. equiseti has been isolated from 17 plant species. It causes stem rot in maize and root rot in winter wheat (4). Isolates of $F$. equiseti were pathogenic on melon and tomato; these results agree with Joffe and Palti (24), who reported that $F$. equiseti is pathogenic on cucurbits. Conversely, Gerlach and Nirenberg (18) believe F. equiseti to be only mildly parasitic and of minor economic importance. F. equiseti pathogenicity did not seem to be related to the origin of the isolates (sea water or fresh water).

F. proliferatum showed pathogenicity on all four plant species prior to emergence. According to Gerlach and Nirenberg (18), $F$. proliferatum var. proliferatum occurs in rice, fig, and orchid and it is responsible for foot rots, fruit rots, and leaf spot. It is a major pathogen in Fusarium crown and root rot diseases in asparagus plants $(11,13)$. As in the case of $F$. equiseti, pathogenicity did not seem to be related to the origin of the isolates.

$F$. solani showed pathogenicity on tree plant species prior to emergence. F. solani was not pathogenic on barley but it caused significant decrease in seedling emergence on melon. F. solani has been described as a pathogen of a large number of plant species, including trees (33), legumes (20), vegetables (42), potato (45), and other tropical plants (37).

Table 4. Incidence of damping off on locally grown plant species inoculated with isolates of Fusarium recovered from river and sea water of south-eastern Spain $^{\mathrm{a}}$

\begin{tabular}{|c|c|c|c|c|c|c|c|c|c|}
\hline \multirow[b]{2}{*}{ Fusarium spp. } & \multirow[b]{2}{*}{ No. ${ }^{\mathbf{b}}$} & \multicolumn{2}{|c|}{ Barley } & \multicolumn{2}{|c|}{ Kohlrabi } & \multicolumn{2}{|c|}{ Melon } & \multicolumn{2}{|c|}{ Tomato } \\
\hline & & Emerg. (\%) & Survival (\%) & Emerg. (\%) & Survival (\%) & Emerg. (\%) & Survival (\%) & Emerg. (\%) & Survival (\%) \\
\hline F. acuminatum & 2 & $45.2 \pm 16.82$ & $42.85 \pm 13.50$ & $28.85 \pm 32.59$ & $28.85 \pm 32.59$ & $90.0 \pm 14.14$ & $36.7 \pm 0.0$ & $65.3 \pm 40.44$ & $55.1 \pm 34.64$ \\
\hline F. chlamydosporum & 3 & $77.76 \pm 11.02$ & $74.6 \pm 5.54$ & $94.9 \pm 5.54$ & $94.9 \pm 5.54$ & $84.46 \pm 3.86$ & $64.43 \pm 9.64$ & $110.2 \pm 2.0$ & $103.56 \pm 8.02$ \\
\hline F. culmorum & 9 & $42.33 \pm 20.94$ & $14.27 \pm 9.50$ & $71.73 \pm 18.79$ & $72.01 \pm 18.85$ & $89.62 \pm 9.04$ & $72.23 \pm 12.56$ & $97.05 \pm 9.63$ & $94.11 \pm 11.70$ \\
\hline F. equiseti & 7 & $34.01 \pm 19.12$ & $33.32 \pm 19.04$ & $45.71 \pm 25.81$ & $45.87 \pm 25.92$ & $89.04 \pm 6.30$ & $56.67 \pm 14.79$ & $76.98 \pm 14.32$ & $74.34 \pm 12.91$ \\
\hline F. oxysporum & 2 & $54.75 \pm 10.11$ & $52.35 \pm 6.71$ & $70.85 \pm 5.44$ & $71.15 \pm 5.44$ & $93.35 \pm 4.73$ & $65.0 \pm 2.40$ & $78.55 \pm 4.31$ & $74.5 \pm 4.38$ \\
\hline F. proliferatum & 5 & $33.32 \pm 32.63$ & $33.32 \pm 32.63$ & $63.08 \pm 35.57$ & $63.08 \pm 35.57$ & $88.0 \pm 7.67$ & $78.66 \pm 9.02$ & $39.74 \pm 44.48$ & $42.46 \pm 45.99$ \\
\hline F. sambucinum & 2 & $57.15 \pm 6.71$ & $16.65 \pm 10.11$ & $97.7 \pm 0.0$ & $98.1 \pm 0.0$ & $88.35 \pm 2.33$ & $66.7 \pm 14.14$ & $100.0 \pm 8.62$ & $95.9 \pm 14.42$ \\
\hline F. solani & 8 & $100 \pm 0.0$ & $100 \pm 0.0$ & $78.75 \pm 20.66$ & $75.63 \pm 21.45$ & $18.13 \pm 9.58$ & $16.89 \pm 9.62$ & $80.41 \pm 27.45$ & $70.0 \pm 37.92$ \\
\hline F. verticillioides & 3 & $55.56 \pm 10.96$ & $55.56 \pm 10.96$ & $90.3 \pm 16.80$ & $90.4 \pm 16.62$ & $86.66 \pm 13.35$ & $66.66 \pm 21.84$ & $77.56 \pm 18.73$ & $49.66 \pm 11.63$ \\
\hline
\end{tabular}

${ }^{\text {a }}$ Greenhouse inoculation studies were repeated; Emerg. = emergence; value \pm standard deviation.

${ }^{\mathrm{b}}$ Number of isolates tested. 
Isolates of $F$. oxysporum were not pathogenic to barley or kohlrabi and only slightly pathogenic on melon and tomato. $F$. oxysporum is distributed worldwide and is extremely common in a wide range of soils $(28,32)$. F . oxysporum is the causal agent of vascular wilts, damping off, and rots on hundreds of different host plants (18) but its pathogenic specialization can be very limited (i.e., formae speciales and races causing wilt diseases). Research has also highlighted specialized forms that induce foot and root rot disease in plants $(23,61)$. Our results suggest that the acquired isolates were slightly pathogenic.

F. acuminatum affected barley and kohlrabi seedlings during emergence and melon and tomato once they emerged. $F$. acuminatum has been reported as causing stem rot in maize. It is also widespread as a foot and root rot of legumes and crown rot in lucerne (4). Elmer (13) described it as a saprophyte in asparagus and Sanders and Cole (43) associated it with Fusarium head blight of wheat and barley.

F. verticillioides isolates caused damping off on barley, melon, and tomato. $F$. verticillioides is a major parasite of several members of Gramineae, including rice, sugar cane, maize, and sorghum. Additionally, $F$. verticillioides may cause diseases such as seedling blights, scorch, foot rot, stunting, and hypertrophy in 31 plant families $(4,18)$, including asparagus $(11,13,51)$ and forest tree nurseries (3). As for other species, $F$. verticillioides pathogenicity did not seem to be related to the origin of the isolates (sea water or fresh water).

This work has revealed some epidemiological information about the genus Fusarium in natural environments. Ten species of Fusarium were isolated from river water. Some of the Fusarium spp. studied are potential mycotoxin producers which exhibit high solubility. The ecotoxicological effects of the presence of mycotoxins in surface waters remain to be elucidated.

Five species of Fusarium were isolated from sea water samples from the Mediterranean Sea 78 days after the last freshet from the river to the sea. There were no algae or vegetation in the sampled area. Our results suggest that the acquired isolates could probably survive in the aquatic habitats as saprophytes. This finding also supports previous hypothesis about the ability to grow in saline media as an adaptive advantage for Fusarium spp. in warm, saline soils $(35,36)$. The increased use of saline water or water coming from desalination plants for crop irrigation in the studied areas underlines the importance of the research.

The results provide information on the biology and distribution of Fusarium spp. and could indicate that pathogenic isolates of Fusarium might be dispersed long distances in water.

\section{ACKNOWLEDGMENTS}

We thank I. F. Herrera and S. Jorreto-Zaguirre (Hydrogeology Department, University of Almeria/Dpto. de Hidrogeología de la Universidad de Almería) for the establishment of the exact localization of sampling points in UTM coordinates.

\section{LITERATURE CITED}

1. Anastasiou, C. J., and Churchland, L. M. 1968. Fungi on decaying leaves in marine habitats. Can. J. Bot. 47:251-257.

2. Backhouse, D., Burgess, L. W., and Summerell, B. A.. 2001. Biogeography of Fusarium. Pages 122-137 in: Fusarium. Paul E. Nelson Memorial Symposium. B. A. Summerell, J. F. Leslie, D. Backhouse, W. L. Bryden, and L. W. Burgess, eds. American Phytopathological Society Press, St. Paul, MN.

3. Bloomberg, W. J. 1981. Diseases caused by Fusarium in forest nurseries. Pages 178-187 in: Fusarium: Diseases, Biology, and Taxonomy. P. E. Nelson, T. A. Toussoun, and R. Cook, eds. The Pennsylvania State University Press, University Park.

4. Booth, C. 1971. The genus Fusarium. Commonwealth Mycological Institute, Kew, Surrey, England.

5. Burgess, L. W. 1981. General ecology of the fusaria. Pages 225-235 in: Fusarium: Diseases, Biology, and Taxonomy. P. E. Nelson, T. A. Toussoun, and R. Cook, eds. The Pennsylvania State University Press, University Park.

6. Burgess, L. W., Backhouse, D., Summerell, B. A., and Swan, L. J. 2001. Crow rot of wheat. Pages 271-294 in: Fusarium: Paul E. Nelson Memorial Symposium. B. A. Summerell, J. F. Leslie, D. Backhouse, W. L. Bryden, and L. W. Burgess, eds. American Phytopathological Society, St. Paul, MN

7. Cabanes, F. J., Alonso, J. M., Castella, G., Alegre, F., Domingo, M., and Pont, S. 1997. Cutaneous Hyalohyphomycosis caused by Fusarium solani in a loggerhead sea turtle (Caretta caretta L.). J. Clin. Microbiol. 12:3343-3345

8. Casas, J. J., and Descals, E. 1997. Aquatic Hyphomycetes from Mediterranean streams contrasting in chemistry and riparian canopy. Limnetica 13:45-55.

9. Charmier, A. C., Dixon, P. A., and Archer, S. A. 1984. The spatial distribution of fungi on decomposing alder leaves in a freshwater stream. Oecology 64:92-103.

10. Corolini, A. 1989. Fusariosis in the shrimp Penaeus semisulcatus cultured in Israel. Mycopathologia 108:145-147.

11. Corpas-Hervias, C., Melero-Vara, J. M., Molinero-Ruiz, M. L., Zurera-Muñóz, C., and Basallote-Úbeda, M. J. 2006. Characterization of isolates of Fusarium spp. obtained from Asparagus in Spain. Plant. Dis. 90:1441-1451.

12. Dill-Macky, R. 2003. Inoculation methods and evaluation of Fusarium head blight resistance in wheat. Pages 184-210 in: Fusarium Head Blight of Wheat and Barley. K. J. Leonard and W. R. Bushnell, eds. American Phytopathological Society, St. Paul, MN.

13. Elmer, W. H. 2001. Fusarium diseases of asparagus. Pages 248-262 in: Fusarium: Paul E. Nelson Memorial Symposium. B. A. Summerell, J. F. Leslie, D. Backhouse, W. L. Bryden, and L. W. Burgess, eds. American Phytopathological Society, St. Paul, MN.

14. Elmer, W. H. 2008. Preventing spread of Fusarium wilt of Hiemalis begonias in the greenhouse. Crop. Prot. 27:1078-1083.

15. Frasca, J., Duna, J. L., and Back, J. D. 1996. Mycotic dermatitis in an Atlantic white-sided dolphin, a pygmy sperm whale, and two harbor seals. J. Am. Vet. Med. Assoc. 208:727-729.

16. Gale, L. R. 2003. Population biology of Fusarium species causing head blight of grain crops. Pages 120-143 in: Fusarium Head
Blight of Wheat and Barley. K. J. Leonard and W. R. Bushnell, eds. American Phytopathological Society, St. Paul, MN.

17. Garet Jones, E. B. 1962. Marine fungi. Trans. Br. Mycol. Soc. 45:93-114.

18. Gerlach, W. L., and Nirenberg, H. 1982. The genus Fusarium. A pictorial atlas. Mitt. Biol. Bundesanst. Land Forstwirtsch. Berlin-Dahlen 209:1-406

19. Gordon, W. L. 1960. The taxonomy and habitats of Fusarium species from tropical and temperate regions. Can. J. Bot. 38:643-658.

20. Grunwald, N. J., Coffman, V. A., and Kraft, J. M. 2003. Sources of partial resistance to Fusarium root rot in the Pisum core collection. Plant Dis. 87:1197-1200.

21. Guirado Moya, M. L., Aguilar, M. I., Blanco, R., Kenig, A., Gómez, J., and Tello, J. C. 2004 Fusarium wilt on sweet basil: cause and sources in southeastern Spain. Phytoparasitica 32:395-401

22. Hatai, K., Kubota, S. S., Kinda, N., and Udagama, S. 1986. Fusarium oxysporum in red sea brean (Pragus sp.). J Wildl. Dis.22:570-571.

23. Jarvis, W. R., and Shoemaker, R. A. 1978 Taxonomic status of Fusarium causing foot and root rot of tomato. Phytopathology 68:1679-1980.

24. Joffe, A. Z., and Palti, J. 1967. Fusarium equiseti (Cda) Sacc. Isr. J. Bot. 16:1-18.

25. Jones, J. P., and Woltz, S. S. 1981. Fusariumincited diseases of tomato and potato and their control. Pages 157-168 in: Fusarium: Diseases, Biology, and Taxonomy. P. E. Nelson, T. A. Toussoun, and R. Cook, eds. The Pennsylvania State University Press, University Park.

26. Khoa, L. V., Hatai, K., and Aoki, T. 2004 Fusarium incarnatum insolated from black tiger shrimp, Penaemus monodon Fabricius, with black gill disease cultured in Vietnam. J. Fish. Dis. 27:507.

27. Komada, H. 1975. Development of a selective medium for quantitative isolation of Fusarium oxysporum from natural soil. Rev. Plant. Prot. Res. 8:114-125.

28. Leslie, J. F., and Summerell, B. A. 2006. The Fusarium Laboratory Manual. Blackwell Publishing, Ames, IA.

29. Messiaen, C. M., Belliard-Alonzol, L., Barriere, Y., and De La Tullaye, B. 1976. Étude qualitative des Fusarium roseum dans les sols des environs de Versailles, sous diverses rotations ou associations végétales. Annu. Rev. Phytopathol. 8:269-282.

30. Moreno, A., Alférez, A., Avilés, M., Diánez, F. Blanco, R., Santos, M., and Tello, J. C. 2001. First report of Fusarium oxysporum f. sp. radicis-cucumerinum on cucumber in Spain. Plant Dis. 85:1206.

31. Nelson, P. E., Horst, R. K., and Woltz, S. S. 1981. Fusarium diseases of ornamental plants. Pages 121-128 in: Fusarium: Diseases, Biology, and Taxonomy. P. E. Nelson, T. A. Toussoun, and R. Cook, eds. The Pennsylvania State University Press, University Park.

32. Nelson, P. E., Toussoun, T. A., and Marasas, W. F. O., eds. 1983. Fusarium Species. A Manual for Identification. The Pennsylvania State University Press, University Park.

33. Nemec, S. 1987. Fusarium solani association with branch and trunk cankers on citrus weakened by cold weather in Florida, USA. Mycopathologia 97:143-150.

34. Nuñez, F. J., Palmero, D., Iglesias, C., De Cara, M., Sinobas, J., and Tello, J. C. 2006. Biogeografía de especies de Fusarium en el litoral mediterráneo de España. Bol. San. Veg. Plagas. 32:137-149.

35. Palmero, D., de Cara, M., Iglesias, C., Ruíz, G., and Tello, J. C. 2008. Effects of water potential on spore germination and viability of Fusarium species. J. Ind. Microbiol. Biotechnol. 35:1411-1418.

36. Palmero, Llamas D., de Cara, M., Iglesias, C., 
Ruíz, G., and Tello, J. C. 2008. The interactive effects of temperature and osmotic potential on the growth of marine isolates of Fusarium solani. J. Ind. Microbiol. Biotechnol. 35:14051409.

37. Pegg, K. G., Willingham, S. L., O'Brien, R. G., Cooke, A. W., and Coates, L. M. 2002. Base rot of golden passionfruit caused by a homothallic strain of Fusarium solani. Aust. Plant Pathol. 31:305-306.

38. Petersen, R. H. 1963. Aquatic hyphomycetes from North America. III. Phialosporae and miscellaneous species. Mycologia 55:570581.

39. Rebell, G. 1981. Fusarium infections in human and veterinary medicine. Pages 210-220 in: Fusarium: Diseases, Biology, and Taxonomy. P. E. Nelson, T. A. Toussoun, and R. Cook, eds. The Pennsylvania State University Press, University Park.

40. Révay, A., and Gönczöl, J. 1990. Longitudinal distribution and colonization patterns of woodinhabiting fungi in a mountain stream in Hungary. Nova Hedwigia 51:505-520.

41. Rhoobunjongde, W., Hatay, K., Wada, S., and Kubota, S. S. 1991. Fusarium moniliforme (Seldon) isolated from gills of kuruna prawn Penaeus japonicus (bate) with black gill disease. Nippon Suisan Gakkaishi 57:629-635.

42. Samac, D. A., and Leong, S. A. 1989. Disease development in Cucurbita maxima squash infected with Fusarium solani f. sp. cucurbitae. Can. J. Bot. 67:3486-3489.

43. Sanders, P., and Cole, H. 1981. The Fusarium diseases of turfgrass. Pages 195-209 in: Fusarium: Diseases, Biology, and Taxonomy. P. E. Nelson, T. A. Toussoun, and R. Cook, eds. The Pennsylvania State University Press, University Park.

44. Schumann, G. L., and D'Arcy, C. J. 2006. Essential plant pathology. American Phytopa- thological Society, St. Paul, MN.

45. Secor, G. A., and Gudmestad, N. C. 1999. Managing fungal diseases of potato. Can. J. Plant Pathol. 21:213-221.

46. Steffenson, B. J. 2003. Fusarium head blight of barley: impact, epidemics, management, and strategies for identifying and utilizing genetic resistance. Pages 241-295 in: Fusarium Head Blight of Wheat and Barley. K. J. Leonard and W. R. Bushnell, eds. American Phytopathological Society, St. Paul, MN.

47. Stoner, M. F. 1981. Ecology of Fusarium in non-cultivated soil. Pages 276-286 in: Fusarium: Diseases, Biology, and Taxonomy. P. E. Nelson, T. A. Toussoun, and R. Cook, eds. The Pennsylvania State University Press, University Park.

48. Tariq, M., Dawar, S., and Mehdi, F. S. 2008. Studies on the rhizosphere mycoflora of mangroves. Turk. J. Bot. 32:97-101.

49. Tello, J. C. 1984. Enfermedades criptogámicas en hortalizas. Comunicaciones INIA. Serie: Protección Vegetal, 22.Instituto Nacional de Investigaciones Agrarias, Madrid.

50. Tello, J. C., Gómez, J., Salinas, J., and Lacasa, A. 1987. La fusariosis vascular del melón en los cultivos de Almería. Cuad. Fitopatol. 10:38-41.

51. Tello, J. C., González, M. L., and Lacasa, A. 1985. The "fusariosis" (diseases produced by Fusarium spp.) of asparagus in Spain. Pages 126-135 in: Proc. 6th Int. Asparagus Symp. University of Guelph, Ontario, Canada.

52. Tello, J. C., and Lacasa, A. 1985. Micosis de las habas (Vicia faba L.). La podredumbre negra del pie. Cuad. Fitopatol. 4:143-160.

53. Tello, J. C., and Lacasa, A. 1988. La podredumbre del cuello y de las raíces causada por Fusarium oxysporum f. sp. radicis-lycopersici, nueva enfermedad en los cultivos de tomate (Lycopersicum esculentum Mill.) españoles.
Bol. San. Veg. Plagas. 14:307-312.

54. Tello, J. C., and Lacasa, A. 1990. Fusarium oxysporum en los cultivos intensivos del litoral mediterráneo de España. Fases parasitaria (Fusariosis vasculares del tomate y del clavel) y no parasitaria. Bol. San. Veg. Plagas. 19:1190.

55. Tello, J. C., Lacasa, A., and Molina, R. 1985. Una nota fitopatológica sobre el complejo parasitario del pie de la judía (Phaseolus vulgaris). ITEA 61:57-69.

56. Tello, J. C., Lacasa, A., and Navas, A. 1988. Prospección de micosis en el cultivo del guisante (Pisum sativum L.) en Murcia. Phytoma España 1:46-53.

57. Tello, J. C., Lacasa, A., and Rodriguez, M. C. 1990. Presence of some Fusarium species on Spanish beaches. Pages 137-138 in: Proc 8th Congr. Mediterr. Phytopathol. Union. Agadir, Morocco.

58. Tello, J. C., Rodriguez, M. C., and Lacasa, A. 1992. Importancia de Fusarium en las arenas de playas de España. ITEA 88:77-94.

59. Tello, J. C., Vares, F., and Lacasa, A. 1991 Análisis de muestras. Pages 39-48 in: Manual de Laboratorio: Diagnostico de Hongos, Bacterias y Nematodos Fitopatógenos. Ministerio de Agricultura Pesca y Alimentación, Madrid, España.

60. Urrutia, M. T., Gomez, V. H., and Tello, J.C.2004. La fusariosis vascular de la berenjena en Almería. Bol. San. Veg. Plagas. 30:8592.

61. Vakalounakis, D. J. 1996. Root and stem rot of cucumber caused by Fusarium oxysporum f. sp. radicis-cucumerinum f. sp. nov. Plant Dis. 80:313-316.

62. Wylloughby, L. G., and Archer, J. F. 1973. The fungal spore in a freshwater stream and its colonization pattern on wood. Freshwater Biol. 3:219-239. 